\title{
Fatty acids as markers of food sources in a shallow- water hydrothermal ecosystem (Kraternaya Bight, Yankich Island, Kurile Islands)
}

\author{
V. I. Kharlamenko, N. V. Zhukova, S. V. Khotimchenko, V. I. Svetashev, \\ G. M. Kamenev
}

Institute of Marine Biology, Russian Academy of Science, Vladivostok 690041, Russia

\begin{abstract}
The contribution of different food sources in the food web of a shallow-water hydrothermal ecosystem was estimated using fatty acids as markers. The markers were selected based on the results of analyzing the fatty acid composition of potential food sources in Kraternaya Bight, Yankich Island, Kurile Islands. Most animals had markers characteristic of diatoms: the 16:0/16:1 1 7 ratio close to 1 and a high 20:5 33 content. We assume that the bivalves Macoma calcarea and Macoma lukini, polychaetes Amphitrite cirrata and Pectinaria hyperborea, and holothurians Eupentacta pseudoquinquesemita and Psolus sp. feed mainly on diatoms. Fatty acids specific to bacteria - branched, odd and 18:167 - were found in considerable amounts in the bivalve Axinopsida orbiculata, as well as in $E$. pseudoquinquesemita, Psolus sp. and P. hyperborea; hence we concluded that there was a substantial bacterial input into the food of these species. A high concentration of $C_{18}$ and $C_{20}$ PUFAs (polyunsaturated fatty acids), suggested to be an indicator of brown algae, was detected merely in the gastropod Littorina kurila. Although bacteria are more important as a food source in Kraternaya Bight than in typical coastal ecosystems, the major food source for animals here is photosynthetic organisms, rather than chemosynthetic symbionts as is the case with deep-sea hydrothermal vents.
\end{abstract}

KEY WORDS: Vent Food web · Fatty acid · Biomarkers

\section{INTRODUCTION}

Shallow-water hydrothermal ecosystems resemble deep-sea vents in many of their characteristics; however, they can differ in the organization of their food webs. The chemoautotrophic symbiotic bacteria-based food web represents a major trophic system in the deep-sea community (Cavanaugh 1983, Jannasch 1985). Shallow-water hydrothermal vent ecosystems and seep ecosystems have a great variety of potential food sources, but little is known about their structure (Fricke et al. 1989, Dando et al. 1991, Jensen et al. 1992).

Among shallow-water hydrothermal ecosystems, Kraternaya Bight (Yankich Island, Kurile Islands) is favorable for the study of the food web structure. Situated in the crater of a volcano, this bight has limited water exchange with the ocean surrounding Yankich Island. Hence, the greater proportion of food is formed in the bight.

Hydrothermal volcanic vents are abundant in Kraternaya Bight (Tarasov \& Zhirmunsky 1989). Extremely high primary productivity and high macrofauna density have been shown here (Tarasov et al. 1990, Sorokin et al. 1993). The food webs in the bight may be based on phytoplankton, benthic micro- and macroalgae, epiphytes, microbial mats and free-living or symbiotic chemoautotrophic bacteria. Stable isotope analysis of animal tissues has been employed to study the role of different food sources in food webs (Fry \& Sherr 1984, Peterson et al. 1985). However, many of the vents in Kraternaya Bight have a high carbon dioxide content, and the $\mathrm{C}_{13} / \mathrm{C}_{12}$ ratio varies widely in these sources of carbon dioxide (Namsaraev 1992). This 


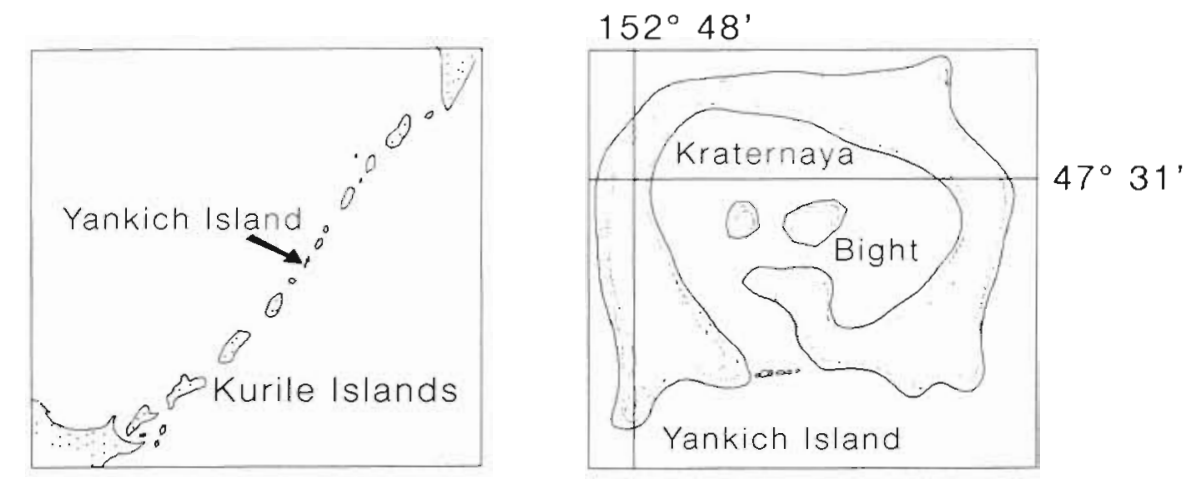

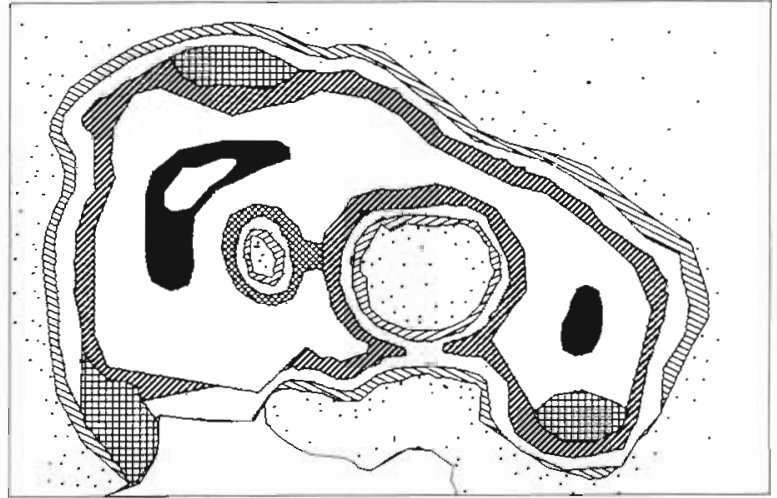

makes the method unsuitable for analysis of the contribution of different food sources to food webs.

Another method for the study of food webs relies on analysis of lipid markers (Nichols et al. 1982, 1986). This approach is based on the specific fatty acid composition of microorganisms and algae and on the inability of animals to synthesize essential polyunsaturated fatty acids (PUFAs). Animals receive a considerable portion of their fatty acids via the diet (Sargent \& Whittle 1981); therefore, comparative analysis of the animal's fatty acid composition and that of potential food sources may be used as a tool for the study of food webs

In the present work, we describe the fatty acid composition of the dominant macrozoobenthic species in Kraternaya Bight and of their potential food. These data are used to determine the importance of different food sources in the food webs of the bight.

\section{MATERIALS AND METHODS}

Samples were collected in Kraternaya Bight during expeditions of the Institute of Marine Biology in August-September 1987, June 1988, and June 1990.

Planktonic diatoms were collected with a plankton net $(100 \mu \mathrm{m}$ mesh) and were allowed to settle in sea water to exclude zooplankton. Seston (particulate $1-\ldots$ Fucus evanescens + Balanus crenatus

2- $\begin{aligned} & \text { Strongylocentrotu } \\ & \text { droebachiensis }\end{aligned}$

3-Wsolus sp. +
Macomalukini

4- Cerianthus so.

$5-\square$ Macoma calcarea + Hiatella arctica

6- Pectinaria

Fig. 1. Location of main communities in Kraternaya Bight organic matter, nanoplankton and picoplankton) samples were prefiltered through a plankton net $(100 \mu \mathrm{m}$ mesh) and collected on a $0.2 \mu \mathrm{m}$ membrane filter. Samples of microbial mats, sediments, macrophytes and animals from depths of 1 to $25 \mathrm{~m}$ were collected by SCUBA divers and from greater depths using a Petersen grab. Animals were collected from the main communities of the bight. Characteristics of the animals and the location of the main communities in the bight, based on the results of hydrobiological studies, are shown in Table 1 and Fig. 1. Before lipid extraction, samples of macrophytes and invertebrates were thoroughly cleaned and washed in sea water. To reduce the time of sample processing, extracts were made from 5 to 10 animals of the same species (or more in the case of small animals). One extract was made for animals difficult to sample - Chone sp. and Amphitrite cirrata - and 2 to 4 extracts were prepared for other species.

All samples were placed in glass vials containing a chloroform-methanol mixture $(1: 1, \mathrm{v} / \mathrm{v})$ and stored at $-20^{\circ} \mathrm{C}$ in this solvent system until analysis. Lipids were extracted by the method of Bligh \& Dyer (1959).

Lipids were transesterified according to the method of Carreau \& Dubacq (1978) and fatty acid methyl esters (FAME) were purified by TLC using benzene as solvent. A GC-9A gas chromatograph with Chromatopack C-R3A integrator (Shimadzu, Kyoto, Japan) 
Table 1. Some characteristics of animals of Kraternaya Bight

\begin{tabular}{|c|c|c|c|}
\hline Animals & $\begin{array}{l}\text { Sampling } \\
\text { depth }(\mathrm{m})\end{array}$ & $\begin{array}{c}\text { Biomass } \\
\left(\mathrm{g} \mathrm{m}^{-2}\right)\end{array}$ & Community \\
\hline \multicolumn{4}{|l|}{ Anthozoa } \\
\hline Cerianthus sp. & $8-40$ & 1414 & 4 \\
\hline \multicolumn{4}{|l|}{ Polychaeta } \\
\hline Amphitrite cirrata & 20 & 16 & 5 \\
\hline Chonesp. & $20-40$ & 68 & 4 \\
\hline \multicolumn{4}{|l|}{ Myxicola } \\
\hline infundibulum & 20 & 25 & 4 \\
\hline \multicolumn{4}{|l|}{ Pectinaria } \\
\hline hyperborea & $35-45$ & 456 & 6 \\
\hline \multicolumn{4}{|l|}{ Crustacea } \\
\hline Balanus crenatus & 0 & 711 & 1 \\
\hline \multicolumn{4}{|l|}{ Gastropoda } \\
\hline Littorina kurila & 0 & 196 & 1 \\
\hline Nucella freycinettii & $0-1$ & 295 & 1 \\
\hline \multicolumn{4}{|l|}{ Bivalvia } \\
\hline Axinopsida orbiculata & $20-40$ & 1 & 5 \\
\hline Hiatella arctica & $20-40$ & 146 & 5 \\
\hline Macoma calcarea & $20-40$ & 379 & 5 \\
\hline Macoma lukini & 20 & 605 & 3 \\
\hline \multicolumn{4}{|l|}{ Echinoidea } \\
\hline \multicolumn{4}{|l|}{ Strongylocentrotus } \\
\hline \multicolumn{4}{|l|}{ Holothurioidea } \\
\hline $\begin{array}{l}\text { Eupentacta pseudo- } \\
\text { quinquesemita }\end{array}$ & $5-10$ & 45 & 3 \\
\hline Psolus sp. & $5-10$ & 1074 & 3 \\
\hline
\end{tabular}

was used for analysis. For FAME separation capillary columns of different polarity were used: glass column ( $43 \mathrm{~m} \times 0.32 \mathrm{~mm}$ ), coated with Silar $5 \mathrm{CP}$; quartz column ( $25 \mathrm{~m} \times 0.32 \mathrm{~mm})$, coated with FFAP; and quartz column $(25 \mathrm{~m} \times 0.32 \mathrm{~mm})$, coated with OV-101. Temperatures of separation were $185^{\circ} \mathrm{C}$ for polar columns (Silar $5 \mathrm{CP}$ and FFAP) and $230^{\circ} \mathrm{C}$ for the nonpolar OV-101 column.

Fatty acids were identified by comparing RTs with those for authentic standards and using Equivalent Chain Length values (Christie 1988). Additionally, AgNO $\mathrm{NO}_{3}$-TLC was used for the identification of unsaturated fatty acids. Peak areas were measured electronically and the fatty acid compositions were expressed as percent of the total integrator response.

Fatty acids were designated as number of carbon atoms : number of double bonds. Double bond position $(\omega)$ is numbered from the methyl end of the fatty acid; all subsequent double bonds are methylene interrupted.

Cluster analysis was performed on the fatty acid marker data using the PC-based computer program 'A MultiVariate Statistical Package', Ver. 2.0. The similarity coefficient was measured and the nearest neighbor method then applied.

\section{RESULTS}

\section{Fatty acids of food sources}

About 60 fatty acid components were detected and identified in samples of macrozoobenthos and potential food sources collected in Kraternaya Bight, but only some of the fatty acids were selected as food source markers. Specific fatty acids in plankton and seston are presented in Fig 2A. High values of 14:0, $16: 0,16: 1 \omega 7$ and 20:5 $\omega 3$, and relatively low concentrations of branched-chain fatty acids, odd-chain fatty acids and 18:167, were observed in planktonic diatoms. The diatom Thalassiosira anguste-lineata was rich in $16: 4 \omega 3,18: 4 \omega 3$ and $20: 5 \omega 3(48.2 \%$ of the total fatty acids). The diatom Chaetoceros debilis had considerably lower levels of these acids $(11.2 \%$ of the total fatty acids) than $T$. anguste-lineata, and the 14:0, 16:0 and 16:1 107 fatty acids predominated. A higher level of

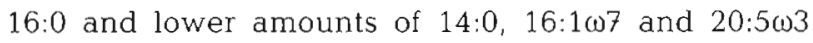
were found in seston less than $100 \mu \mathrm{m}$.

Microbial mats were found in the littoral and sublittoral zones of the bight. They were formed by diatoms alone or diatoms in combination with bacteria. The biomass of all the microbial mats was dominated by diatoms, except for some of the southeastern sublittoral mats, which were dominated by Thiodendron $\mathrm{sp}$.

The littoral microbial mats were sampled in the eastern and southeastern regions of the bight. Littoral mats collected near the hydrothermal vents were formed by the diatom Thalassiosira anguste-lineata, blue-green algae, phototrophic purple bacteria and colorless sulfur bacteria Thiothrix sp. (Starynin et al. 1989). Fatty acids typical of diatoms and bacteria were found in these mats (Fig. 2B). Diatoms in the mats, as in the plankton, exhibited high concentrations of 14:0, 16:0, 16:1 $1 \omega 7$ and $20: 5 \omega 3$. The amount of $16: 1$ exceeded that of $16: 0$. In these mats $18: 1 \omega 7$ made up $10.7 \%$ of total fatty acids, and branched fatty acids comprised a few percent. The major fatty acids of purple bacteria from

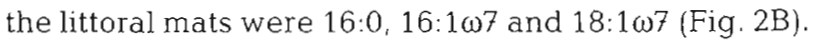
Small amounts of branched acids were present in purple bacteria from littoral mats.

Sublittoral microbial mats were found in the southeastern, eastern and northern parts of the bight. In the southeastern part of the bight the mats were rich in colorless sulfur bacteria Thiodendron $\mathrm{sp}$. The main fatty acids of these mats were $16: 0$ and $16: 1 \omega 7$ (Fig. 2B). The sum of branched and odd-chain fatty acids in these mats was very high (up to $14.4 \%$ of total fatty acids). This distinguishes them from the littoral microbial mats in Kraternaya Bight and from the Thiothrix-like bacterial mats sampled near the subtidal hydrothermal vents in the eastern cove of White Point, California, USA (Jacq et al. 1989). 

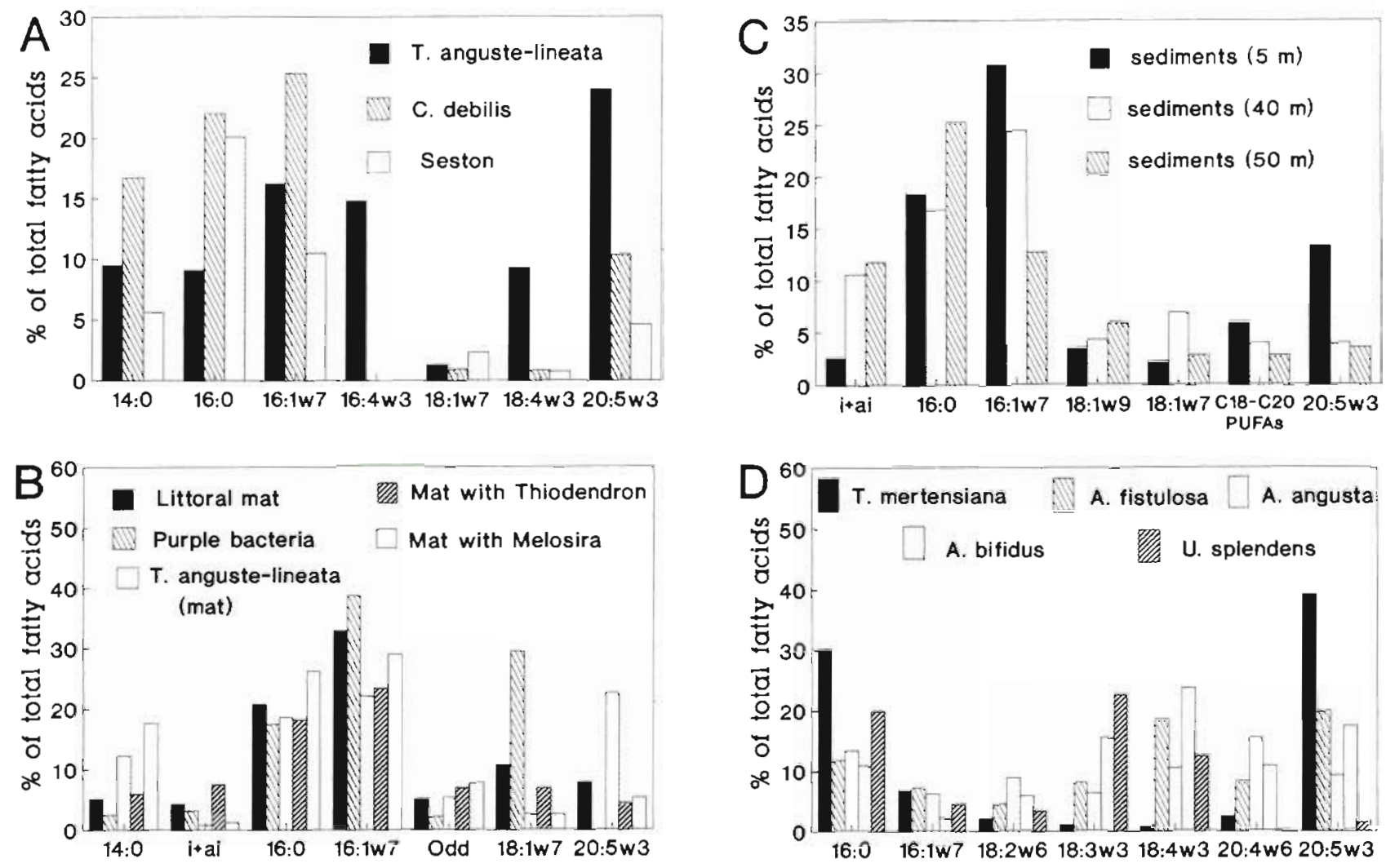

Fig. 2. Content of specific fatty acids in: (A) diatoms Thalassiosira anguste-ineata, Chaetoceros debilis and seston, (B) microbial mats, (C) sediments, (D) macroalgae Turnerella mertersiana, Alaria fistulosa, Alaria angusta, Arthrothamnus bifidus and Ulvaria splendens. i+ai: iso and anteiso (branched) fatty acids

The diatom Melosira sp. predominated in the microbial mats from the eastern part of the bight. The fatty acid composition of these mats was typical of diatoms, and in addition they contained high concentrations of odd-chain fatty acids (Fig. 2B). In the northern part of the bight the microbial mats were dominated by diatoms, and their fatty acid composition was similar to that of mats from the eastern sublittoral zone.

The major fatty acids detected in the sediments of Kraternaya Bight were 14:0, 16:0 and 16:167, which together constituted 45.1 to $59.5 \%$ of the total fatty acids. The 16:0/16:1 7 ratio was low. With an increase in depth from $5 \mathrm{~m}$ to $50 \mathrm{~m}$, the concentration of bacterial fatty acids (odd-chain and branched) in sediments increased from $8.2 \%$ to $18.9 \%$ and the concentration of $20: 5 \omega 3$ decreased from $13.5 \%$ to $3.5 \%$ (Fig. 2C).

Macroalgae differed from other potential food sources and contained high levels of the $C_{18}$ and $C_{20}$ PUFAs (Fig. 2D). A large amount of 20:5 13 (39.2\%) was found in the red alga Turnerella mertensiana. The green alga Ulvaria splendens was rich in the 13 PUFAs

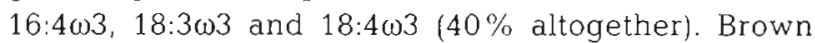
algae contained high concentrations of $C_{18}$ and $C_{20}$ PUFAs. The major PUFAs were 18:4 13 in Alaria fistu- losa and Arthrothamnus bifidus and 20:4w6 in Alaria angusta and Fucus evanescens.

\section{Fatty acids as markers of food sources}

The potential food sources in Kraternaya Bight were differentiated on the basis of the following markers: (1) the ratio of $16: 0 / 16: 1 \omega 7 ;$ (2) the sum of branched fatty acids; (3) the concentration of $18: 1 \omega 7$; (4) the sum of $18: 2 \omega 6,18: 3 \omega 3,18: 3 \omega 6,18: 4 \omega 3,20: 2 \omega 6$ and $20: 4 \omega 6$ $\left(C_{18}\right.$ and $C_{20}$ PUFAs); (5) the concentration of 20:5 03 ; (6) the concentration of 22:6w3. Table 2 shows the values of these markers for the potential food sources in the bight.

We used the 16:0/16:1 117 ratio as a marker of diatoms and bacteria. The ratio was less than 1 in planktonic diatoms and most of the microbial mats and sediments; it was 2 in seston and varied from 1.7 to 8.3 in macroalgae.

The presence in a food source of a large amount of bacteria resulted in high concentrations of 18:167 or odd-chain and branched fatty acids. Lipids of microbial mats and sediments were rich in bacterial fatty acids. 
Table 2. 16:0/16:107 ratio and percentage levels of fatty acid markers (\% of total fatty acids) in food sources in Kraternaya Bight.



\begin{tabular}{|c|c|c|c|c|c|c|}
\hline Food source & Ratio 16:0/16:1 $1 \omega 7$ & Branched & $18: 1 \omega 7$ & $20: 5 \omega 3$ & $\mathrm{C}_{18} \& \mathrm{C}_{20}$ PUFAs & $22: 6 \omega 3$ \\
\hline \multicolumn{7}{|l|}{ Water column } \\
\hline Thalassiosira anguste-lineata & 0.6 & 4.0 & 1.3 & 24.1 & 11.2 & 3.1 \\
\hline Chaetoceros debilis & 0.9 & 6.2 & 0.9 & 10.4 & 3.6 & 0.7 \\
\hline Seston & 2.0 & 5.9 & 2.3 & 4.6 & 8.2 & 2.2 \\
\hline \multicolumn{7}{|l|}{ Microbial mats } \\
\hline Littoral mat & 0.6 & 4.2 & 10.7 & 7.8 & 6.3 & 1.2 \\
\hline Purple bacteria & 0.4 & 3.1 & 29.4 & 0 & 1.8 & 0.1 \\
\hline Thalassiosira anguste-lineata & 0.8 & 0.8 & 2.5 & 22.6 & 5.5 & 1.4 \\
\hline Mat with Thiodendron sp. & 0.8 & 7.5 & 6.9 & 4.3 & 4.0 & 2.0 \\
\hline Mat with Melosira sp. & 0.9 & 1.2 & 2.6 & 5.3 & 2.5 & 0.3 \\
\hline \multicolumn{7}{|l|}{ Sediments } \\
\hline $50 \mathrm{~m}$ & 2.0 & 11.8 & 2.8 & 3.5 & 2.8 & 0.0 \\
\hline $30-40 \mathrm{~m}$ & 0.7 & 10.6 & 6.9 & 4.0 & 4.0 & 0.7 \\
\hline $5 \mathrm{~m}$ & 0.6 & 2.7 & 2.2 & 13.4 & 6.0 & 2.0 \\
\hline \multicolumn{7}{|l|}{ Macrophytes } \\
\hline Turnerella mertensiana & 4.5 & 0.8 & 0.9 & 39.2 & 6.8 & 0.0 \\
\hline Ulvaria splendens & 4.4 & 1.3 & 0.0 & 1.4 & 39.3 & 0.0 \\
\hline Alaria angusta & 2.2 & 2.0 & 0.0 & 9.0 & 47.5 & 0.0 \\
\hline Alaria fistulosa & 1.7 & 2.5 & 0.0 & 19.6 & 40.1 & 0.0 \\
\hline Arthrothamnus bifidus & 5.1 & 0.8 & 0.0 & 17.2 & 56.6 & 0.0 \\
\hline Fucus evanescens & 8.3 & 0.2 & 0.0 & 10.0 & 35.4 & 0.0 \\
\hline
\end{tabular}

The 18:1 107 acid comprised $10.7 \%$ of the total fatty acids in littoral microbial mats, 2.2 to $6.9 \%$ in sediments, 0.9 to $1.3 \%$ in plankton and $2.3 \%$ in seston. Among macrophytes, this fatty acid occurred only in the red alga Turnerella mertensiana $(0.9 \%$ of total fatty acids). The concentration of branched fatty acids was higher in sediments at a depth of 40 to $50 \mathrm{~m}$ (10.6 and $11.8 \%$ of the total fatty acids) compared with other food sources: 4.0 to $6.2 \%$ in plankton, 0.8 to $7.5 \%$ in microbial mats and 0.2 to $2.5 \%$ in algae.

The presence in food of a significant amount of brown algae accounts for the high concentrations of

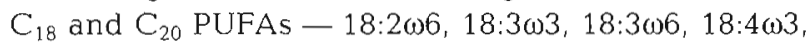

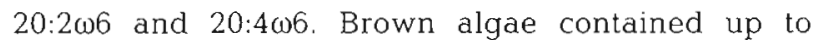
$56.6 \%$ of these acids. The proportion of these acids varied in planktonic diatoms, microbial mats and sediments from 1.8 to $11.2 \%$.

The acid 20:503 was found in high concentrations in planktonic diatoms (10.4 and $24.1 \%$ of the total fatty acids) and brown and red macroalgae (9 to $19.6 \%$ and $39.2 \%$, respectively). The concentration of $20: 5 \omega 3$ in the microbial mats and sediments was lower.

The concentration of $22: 6 \omega 3$ was low in all potential food sources and did not exceed $3.1 \%$.

\section{Fatty acid markers in macrozoobenthos}

Fatty acid markers in macrozoobenthos are shown in Table 3 . The 16:0/16:1 17 ratio varied from 0.6 in the bivalve Macoma calcarea to 6.6 in the gastropod Nucella freycinettii. The animals in the bight may be divided into 2 groups: (1) those in which the $16: 0 / 16: 1 \omega 7$ ratio is less than 2 , and (2) those in which it is greater than 2 .

The ratio was less than 2 in the majority of animals. This group of animals had only 2.7 to $9.7 \%$ of $\mathrm{C}_{18}$ and $\mathrm{C}_{20}$ PUFAs and a relatively low level of 22:603. Many of them also had elevated levels of branched (iso and anteisol acids or $18: 1 \omega 7$. However, in the bivalves Macoma calcarea and $M$. lukini and in the barnacle Balanus crenatus, bacterial fatty acids were present in low concentrations.

Small amounts of bacterial fatty acids were found in the bivalve Mya uzenensis, the gastropods Littorina kurila and Nucella freycinettii, the coral Cerianthus sp. and the polychaete Myxicola infundibulum, which had a 16:0/16:1 107 ratio greater than 2 . Several animals from this group contained large amounts of $C_{18}$ and $C_{20}$ PUFAs and others had high concentrations of $22: 603$.

A dendrogram of the similarity of marker profiles for macrozoobenthos reveals 7 groupings if a critical similarity of $75 \%$ is applied (Fig. 3).

Cluster I represents all dominant bivalves, the polychaete Amphitrite cirrata and the barnacle Balanus crenatus. These animals had high amounts of $20: 5 \omega 3$ and low concentrations of bacterial and macroalgalderived fatty acids. The ratio of $16: 0$ to $16: 1 \omega 7$ was mostly less than 2 in these animals. Similar marker profiles were observed for animals from Clusters II and III; 
however, they had the highest concentration of $\mathrm{C}_{18}$ and $\mathrm{C}_{20}$ PUFAs. Cluster IV consists of animals having the highest concentration of branched fatty acids. Cluster $\mathrm{V}$ contains 1 species, the polychaete Pectinaria hyperborea, which had high concentrations of both bacterial and diatom fatty acids. Cluster VI represents Chone sp. and 2 other species, which had the highest concentration of 22:6w3. Cluster VII comprises the bivalve Axinopsida orbiculata which contained the highest concentration of $18: 1 \omega 7$ and the lowest concentration of PUFAs.

\section{DISCUSSION}

Analysis of the fatty acids in the main food sources in Kraternaya Bight has allowed us to identify marker fatty acids (Table 2). These markers were used to determine the major food sources of macrozoobenthos in this shallow-water hydrothermal ecosystem.

Hydrothermal ecosystems are different from other marine ecosystems in that they have significantly higher concentrations and diversity of bacteria. Hence, bacteria can be regarded as an important potential food source in such ecosystems. Branched acids and 18:1 107 were used as bacterial markers. The same fatty acids are usually used to determine the input of bacteria into organic matter of sediments (Volkman et al. 1980) or particulate organic matter (Currie \& Johns 1988). The concentration of 18:1 1 7 in animals does not generally exceed $10 \%$ of the total fatty acids, except

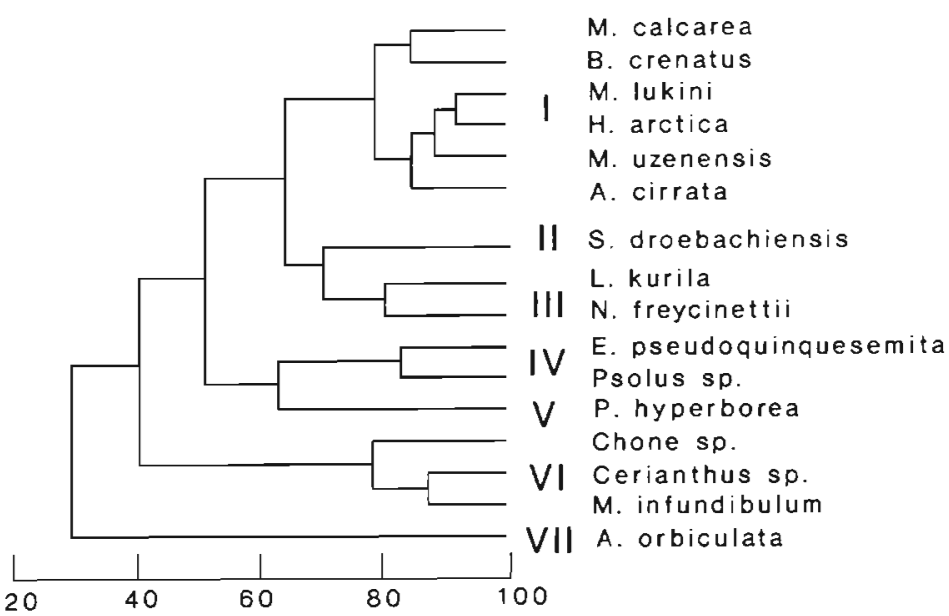

Fig. 3. Cluster analysis dendrogram of macrozoobenthic species in Kraternaya Bight, showing similarity levels of their marker profiles. See text for discussion

for molluscs with bacterial symbionts (Convey \& McDowell Capuzzo 1991, Zhukova et al. 1992). Elevated levels of branched fatty acids have been reported in animals with bacterial symbionts (Berg et al. 1985) and in animals from muddy sediments (Takagi et al. 1986. Svetashev et al. 1991). In this study all species of macrozoobenthos had higher concentrations of bacterial fatty acids compared to corresponding animals in other marine coastal ecosystems. We suggest, therefore, that bacteria are more significant as food for macrozoobenthos in Kraternaya Bight.

Bacterial fatty acids were detected in high concentration in the polychaete Pectinaria hyperborea and the holothurians Eupentacta pseudoquinquesemita

Table 3. 16:0/16:1 $\omega$ 7 ratio and percentage levels of fatty acid markers (\% of total fatty acids) in animals in Kraternaya Bight

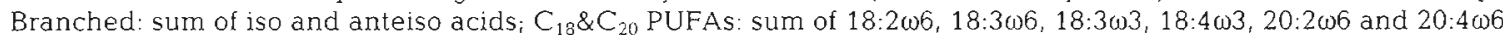

\begin{tabular}{|c|c|c|c|c|c|c|}
\hline Animal & atio $16: 0 / 16: 1$ & Branched & $18: 1 \omega 7$ & $20: 5 \omega 3$ & $\mathrm{C}_{18} \& \mathrm{C}_{20}$ PUFAs & $22: 6 \omega 3$ \\
\hline Cerianthus sp. & 4.0 & 2.4 & 2.2 & 14.4 & 3.2 & 27.8 \\
\hline Amphitrite cirrata & 1.0 & 4.7 & 4.5 & 22.5 & 2.7 & 5.2 \\
\hline Chone sp. & 0.8 & 4.6 & 4.6 & 14.5 & 6.2 & 14.8 \\
\hline Myxicola infundibulum & 3.0 & 2.4 & 2.7 & 20.0 & 6.6 & 22.7 \\
\hline Pectinaria hyperborea & 2.0 & 13.4 & 6.3 & 11.9 & 5.3 & 3.7 \\
\hline Balanus crenatus & 1.7 & 0.1 & 2.6 & 31.4 & 5.6 & 9.2 \\
\hline Littorina kurila & 3.1 & 0.6 & 1.2 & 22.6 & 18.3 & 0.7 \\
\hline Nucella freycinettii & 6.6 & 0.9 & 1.0 & 22.4 & 10.0 & 2.8 \\
\hline Axinopsida orbiculata & 0.8 & 2.2 & 24.0 & 4.3 & 7.0 & 3.2 \\
\hline Hiatella arctica & 2.1 & 3.2 & 2.4 & 20.7 & 5.4 & 7.9 \\
\hline Macoma calcarea & 0.6 & 3.6 & 1.6 & 26.8 & 5.6 & 3.9 \\
\hline Macoma lukini & 1.3 & 2.7 & 1.8 & 24.3 & 6.1 & 8.7 \\
\hline Mya uzenensis & 3.7 & 2.3 & 2.2 & 22.6 & 6.8 & 13.5 \\
\hline Strongylocentrotus droebachiensis & 1.7 & 2.0 & 4.7 & 14.8 & 8.8 & 0.7 \\
\hline Eupentacta pseudoquinquesemita & 0.3 & 24.9 & 2.8 & 24.8 & 3.9 & 2.3 \\
\hline Psolus sp & 0.9 & 20.1 & 1.5 & 34.2 & 5.7 & 1.1 \\
\hline
\end{tabular}



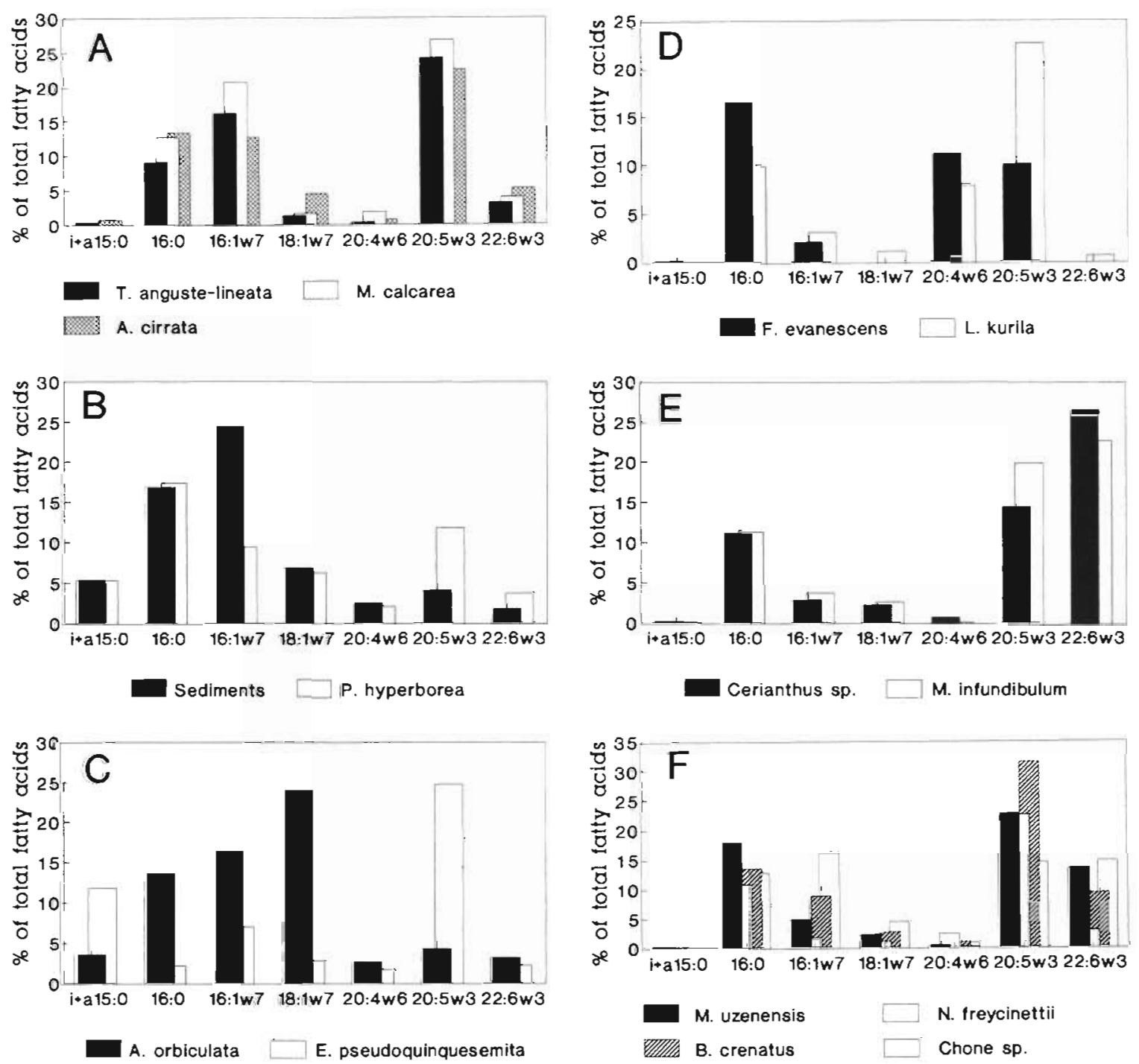

Fig. 4. Distribution of fatty acid markers in: (A) the diatom Thalassiosira anguste-lineata and diatom consumers Macoma calcarea and Amphitrite cirrata (Cluster I); (B) sediments from 30 to $40 \mathrm{~m}$ depth and the deposit feeder Pectinaria hyperborea (Cluster V); (C) the bivalve Axinopsida orbiculata (Cluster VII) and the holothurian Eupentacta pseudoquinquesemita (Cluster IV); (D) Fucus evanescens and the herbivore Littorina kurila (Cluster III); (E) the carnivores Cerianthus sp. and Myxicola infundibulum (Cluster $\mathrm{VI}) ;(\mathrm{F})$ the omnivores Mya uzenensis, Nucella freycinettii, Balanus crenatus and Chone sp.

and Psolus sp. High concentrations of $20: 5 \omega 3$ were also found in these animals. In cluster analysis, these animals fell within 2 clusters, IV and $V$, situated close to one another, but distant from other clusters.

Pectinaria hyperborea is a deposit feeder. There was some similarity in the marker profiles of P. hyperborea and those of sediments (Fig. 4B). The levels of bacterial acids in sediments and $P$. hyperborea were very high, while in other animals (with exception of Psolus sp. and Eupentacta pseudoquinquesemita) their concentrations were much lower. Hence, marine-sediment bacteria rich in iso and anteiso acids make a considerable contribution to the food of $P$. hyperborea. At the same time, we noted a high concentration of 20:503, which probably derived from microalgae. The role of macroalgae and animals in the nutrition of $P$. hyperborea was insignificant.

Eupentacta pseudoquinquesemita and Psolus sp. had unusual fatty acids profiles (Fig. 4C). Large amounts of both branched fatty acids (24.9\%) and $20: 5 \omega 3(34.2 \%)$ were found in these animals. The concentration of $16: 1 \omega 7$ much exceeded that of 16:0. Such a combination of markers may be observed in consumers using diatoms and large quantities of bacteria or microbial mats as food sources. E. pseudoquinquesemita and Psolus sp, are suspension-feeders and it 
seems doubtful that they use microbial mats. Microscopic examination of the gut contents revealed a large amount of planktonic diatoms as well as free-living bacteria and ciliates. No organisms constituting the mats studied were found. It may well be that diatoms were used as the main food source and bacteria were involved in food transformation.

Fatty acid markers proved useful in the study of endosymbiosis, since the appearance of endosymbiotic bacteria produces significant changes in the fatty acid composition of the host. Animals feeding on symbiotic bacteria are expected to have high concentrations of bacterial fatty acids and low concentrations of PUFAs (Convey \& McDowell Capuzzo 1991, Zhukova et al. 1992). Symbiotic bacteria proved of little importance as a food source in Kraternaya Bight, as none of the dominant species of macrozoobenthos had this combination of marker fatty acids. Only the small bivalve Axinopsida orbiculata exhibited such a fatty acid profile (Fig. 4C). This mollusc fell into Cluster VII located far from all others. The existence of symbiotic bacteria in A. orbiculata was supported by examination of the sections of the mollusc gill tissue. Bacteriocytes containing 2 morphological groups of bacteria were found in this tissue (Zhukova et al. 1991).

The use of bacteria from bacterial mats growing at southern Californian intertidal hydrothermal vents has been demonstrated for the black abalone Haliotis cracherodii (Stein 1984) and the limpet Lottia limatula (Trager \& DeNiro 1990). None of the species living at the hydrothermal vents in Kraternaya Bight, with the exception of the sea urchin Strongylocentrotus droebachiensis, used bacteria from microbial mats in considerable amounts.

Among the markers, the 16:0/16:1 107 ratio is in our view of special interest. A predominance of $16: 1 \omega 7$ has been shown for diatoms (Ackman et al. 1968, Volkman et al. 1989) and many bacteria (Wilkinson 1988). High concentrations of this acid have been detected in animals which feed on diatom-rich plankton. The 16:0/16:1 17 ratio varies from 1 in the bivalve $M a-$ coma balthica (Wenne \& Polak 1989) to 2 in the euphausiid Euphausia superba (Fricke et al. 1984). The addition of diatoms to food produces a significant decrease in the 16:0/16:1 $1 \omega^{7}$ ratio (Marsh et al. 1990). The same effect can be also expected when animals feed on bacteria with a low 16:0/16:1 107 ratio. We believe that animals having a 16:0/16:1 107 ratio of about 1 , a high concentration of $20: 5 \omega 3$ and low concentrations of bacterial fatty acids feed predominantly on diatoms. Planktonic diatoms in Kraternaya Bight exhibit exceedingly high production and biomass values which are not usually found in marine ecosystems (Sorokin et al. 1993); benthic diatoms occur in very high concentrations and comprise the bulk of micro- bial mats, which are tens of centimeters thick (Tarasov \& Zhirmunsky 1989).

Analysis of the fatty acid composition of the dominant macrozoobenthic species leads to the conclusion that diatoms are the major food source in Kraternaya Bight. The bivalves Macoma lukini and $M$. calcarea contained mainly diatom markers. Fatty acid profiles of these species were similar to that of Thalassiosira anguste-lineata. (Fig. 4A). A relationship between the high biomass of $M$. balthica and periods of diatom blooms has been reported (Beukema \& Cadee 1991), hence high densities of $M$. calcarea and M. lukini can be expected in this bight, which has regular diatom blooms.

On the basis of the $16: 0 / 16: 1 \omega 7$ ratio and the relative level of 20:5 13 , we conclude that diatoms are the dominant food source for the holothurians Eupentacta pseudoquinquesemita and Psolus sp. Benthic diatoms are also an important food for the polychaetes Pectinaria hyperborea and Amphitrite cirrata.

In addition, diatoms were used by Strongylocentrotus droebachiensis. Indirect evidence for a shift to feeding mainly upon microalgae is provided by the small size of sea urchins in this bight. It is known that when $S$. droebachiensis shifts from macrophytal to microalgal food its size decreases by several times (Mann 1982).

Furthermore, diatoms are an important dietary component for Chone sp., Balanus crenatus, Hiatella arctica, and Mya uzenensis.

Kamenev (1991) determined the proportion of the bivalves Macoma calcarea and Macoma lukini, holothurians Eupentacta pseudoquinquesemita and Psolus sp., polychaetes Pectinaria hyperborea and Amphitrite cirrata and sea urchin Strongylocentrotus droebachiensis in the biomass of sublittoral communities. These species' biomass constituted 57.4 to $93.5 \%$ of the macrozoobenthic biomass in the sublittoral communities of Kraternaya Bight, except in the Cerianthus sp. and $M$. lukini community. In latter community, the biomass of animals which fed on diatoms accounted for only $19.1 \%$ of the total macrozoobenthic biomass.

In elucidating the role of macrophytes in food webs, PUFAs usually serve as specific markers. The presence of green algae is indicated by the level of 16:4 33 (Johns et al. 1979), and of seagrasses by 18:206 and 18:3w3 (Nichols et al. 1982).

Brown algae were found in high densities in Kraternaya Bight. We used the sum of $18: 2 \omega 6,18: 3 \omega 3$, $18: 3 \omega 6,18: 4 \omega 3,20: 2 \omega 6$ and $20: 4 \omega 6$ as a marker of this food source. High concentrations of these $C_{18}$ and $C_{20}$ PUFAs were detected in the gastropods Littorina kurila and Nucella freycinettii. These gastropods comprised Cluster III. The fatty acid profile of $L$. kurila was very similar to that of Fucus evanescens (Fig. 4D). There 
was no difference between the fatty acid composition of $L$. kurila at the hydrothermal vents and that of $L$. kurila collected from $F$. evanescens growing far away from the vents. Bacteria and diatoms did not make any significant contribution to the nutrition of L. kurila, which is especially surprising since epiphytic diatoms occur very abundantly.

Nucella freycinettii is regarded as a carnivore, but individuals collected from Kraternaya Bight contained fatty acids characteristic of herbivorous animals. Among the fatty acids of this predator we expected a high level of 22:6 $\omega 3$, characteristic of carnivores. However, the concentration of this acid was low, which may have been compensated for by 22:5w3. N. freycinettii prey upon Balanus crenatus, but this food source may be insufficient. It is reasonable to suppose that in Kraternaya Bight $N$. freycinettii also feeds on the brown algae Fucus evanescens. This predator occurred in Cluster III, together with L. kurila. Cluster II was closest to Cluster III and contained the sea urchin Strongylocentrotus droebachiensis, which had fatty acid markers characteristic of macrophytes and of diatoms and bacteria.

We used 22:6w3 as a marker for carnivores. This acid occurs in Dinophyceae, Haptophyceae and Cryptophyceae (Sargent et al. 1987, Cobelas \& Lechado 1989), hence it is not useful as marker of carnivores in ecosystems with significant densities of these microalgae. In Kraternaya Bight the biomass of these algae was low, however; thus, we felt justified in using 22:6w3 as carnivore marker. High concentrations of this fatty acid were found in the coral Cerianthus sp. and the polychaete Myxicola infundibulum. The fatty acid profiles of these animals differed from those of other animals in Kraternaya Bight (Fig. 4E). Together with Chone sp. - which contained other markers besides 22:6 13 - they constituted Cluster VI. Some authors have assumed that bacterial endosymbionts are present in Cerianthus volttii due to the ability of these anthozoans to accumulate at seep sites (Jensen 1992). Judging by their fatty acid composition, it can be inferred that the Cerianthus sp. we observed contained no bacterial endosymbionts. The dominant group in the gastric cavity of Cerianthus sp. from Kraternaya Bight was crustaceans; Cocconeis sp. diatoms were also common (Moshchenko \& Gladkov 1991).

The presence of several markers implies the use of different food sources (Fig. 4F). On this basis, the gastropod Nucella freycinettii, the barnacle Balanus crenatus, the bivalve Mya uzenensis, the sea urchin Strongylocentrotus droebachiensis and the polychaete Chone sp. receive food from several sources. Chonesp.

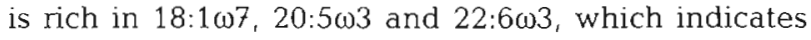
feeding on bacteria, algae and animals. $B$. crenatus feeds on diatoms and zooplankton; however, it does not use bacteria in any detectable amounts, even near the littoral hydrotherms. The bivalve $M$. uzenensis uses both diatoms and animals as food. Most omnivores occurred in the same cluster as animals feeding on diatoms.

One of the primary producers in Kraternaya Bight is the ciliate Mesodinium rubrum. It should be stressed that $C_{18}$ PUFAs, characteristic of $M$. rubrum (Dikarev 1985), were not found in large amounts in animals from

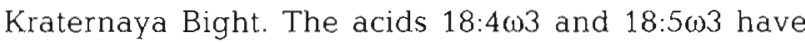
been used as markers of microalgae in planktonic food webs (Mayzaud et al. 1976, Sargent et al. 1987). Calanus which fed on the dinoflagellate Scrippsiella trochoidea did not accumulate 18:503 in lipids,

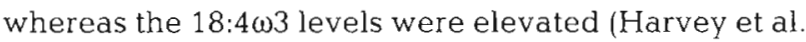
1987).

In summary, diatoms are the major food source in Kraternaya Bight. This points to the conclusion that the trophic structure of shallow-water hydrothermal ecosystems differ from that of deep-sea hydrothermal ecosystems. Despite the fact that bacteria are more important as a food source in Kraternaya Bight than in typical coastal ecosystems, the major food source here is photosynthetic organisms, rather than chemosynthetic symbionts as is the case with deep-sea hydrothermal vents.

Acknowledgements. This work was funded in part by grants from The International Science Foundation, initiated by G. Soros, and the Russian Fund of Fundamental Research, N 94 . 04-12512-a.

\section{LITERATURE CITED}

Ackman, R. G., Tocher, C. S., McLachlan, J. (1968). Marine phytoplankter fatty acids. J. Fish. Res. Bd Can. 25: $1603-1620$

Berg, C. J. Jr, Krzynowek, J., Alatalo, P., Wiggin, K. (1985). Sterol and fatty acid composition of the clam, Codakia orbicularis, with chemoautotrophic symbionts. Lipids 20 : $116-120$

Beukema, J. J, Cadee, G. C. (1991). Growth rates of the bivalve Macoma balthica in the Wadden Sea during a period of eutrophication - relationships with concentrations of pelagic diatoms and flagellates. Mar. Ecol. Prog. Ser. 68: 249-256

Bligh, E. G., Dyer, W. J. (1959). A rapid method of total lipid extraction and purification. Can. J. Biochem. Physiol. 37: 911-917

Carreau, J. P., Dubacq, J. P. (1978). Adaptation of macro-scale method to the micro-scale for fatty acid methyl transesterification of biological lipid extracts. J. Chromatogr. 151: $384-390$

Cavanaugh, C. M. (1983). Symbiotic chemoautotrophic bacteria in marine invertebrates from sulfide-rich habitats. Nature 302: 58-61

Christie, W. W. (1988). Equivalent chain-lengths of methyl ester derivatives of fatty acids on gas chromatography. $J$. Chromatogr. 447: 305-314

Cobelas, M. A., Lechado, J. Z. (1989). Lipids in microalgae. A 
review I. Biochemistry. Grasas Aceites 40: 118-145

Convey, N., McDowell Capuzzo, J. (1991). Incorporation and utilization of bacterial lipids in the Solemia velum symbiosis. Mar. Biol. 108: 277-291

Currie, B. R., Johns R. B. (1988). Lipids as indicator of the origin of organic matter in fine marine particulate matter. Aust. J. mar. Freshwat. Res. 39: 371-383

Dando, P. B., Austen, M. C., Burke, R. A., Kendall, M. A., Kennicutt, M. C. II, Judd, A. G., Moore, D. C., O'Hara, S. C. M., Schmaljohann, R, Southward, A. J. (1991). Ecology of a North Sea pockmark with an active methane seep. Mar. Ecol. Prog. Ser. 70: 49-63

Dikarev, V. P. (1985). Polar lipids and fatty acids of the infusorian Mesodinium rubrum from a red tide in Avacha Bay (Kamchatka). Biol Morya 3: 58-63

Fricke, H., Gercken, G., Schreiber, W., Oehlenschlager, J. (1984). Lipids, sterol and fatty acid composition of antarctic krill (Euphausia superba, Dana). Lipids 19: 821-827

Fricke, H., Giere, O., Stetter, K., Alfredsson, G. A., Kristjansson, J. K., Stoffers, P., Svavarsson, J. (1989). Hydrothermal vent communities at the shallow subpolar mid-Atlantic ridge. Mar. Biol. 102: 425-429

Fry, B., Sherr, E. (1984). $\delta^{13} \mathrm{C}$ measurements as indicator of carbon flow in marine and freshwater ecosystems. Contrib. mar. Sci. 27: 15-47

Harvey, H. R., Eglinton, G., O'Hara, S. C. M., Corner, E. D. S. (1987). Biotransformation and assimilation of dietary lipids by Calanus feeding on a dinoflagellate. Geochim. Cosmochim. Acta 51: 3031-3040

Jacq, E., Prieur, D., Nichols, P., White, D. C., Porter, T., Geesey, G. G. (1989). Microscopic examination and fatty acid characterization of filamentous bacteria colonizing substrata around subtidal hydrothermal vents. Arch. Microbiol. 152: 64-71

Jannasch, H. W. (1985). The chemosynthetic support of life and the microbial diversity at deep-sea hydrothermal vents. Proc. R. Soc. Lond. B 225: 277-297

Jensen, P. (1992). Cerianthus voltii Danielsen, 1890 (Anthozoa, Ceriantharia) - a species inhabiting an extended tube system deeply buried in deep-sea sediments off Norway. Sarsia 77: 75-80

Jensen, P., Aagaard, I., Burke, R. A., Dando, P. R., Jorgensen, N. O., Kuijpers, A., Laier, T., O'Hara, S. C. M., Schmaljohann, R. (1992). Bubbling reefs in the Kattegat: submarine landscapes of carbonate-cemented rocks support a diverse ecosystem at methane seeps. Mar. Ecol. Prog. Ser. 83: $103-112$

Johns, R. B., Nichols, P. D., Perry, G. J. (1979). Fatty acid composition of ten marine algae from Australian waters. Phytochemistry 18: 799-802

Kamenev, G. M. (1991). Sublittoral macrobenthos in the Kraternaya Bight. Communities distribution. In: Shallowwater vents and ecosystem of Kraternaya Bight (Volcano Ushishir, Kurile Islands), Vol. 2, Biota. DVO RAN, Vladivostok, p. 92-137 (in Russian)

Mann, K. H. (1982). Kelp, sea urchins and predators - a review of strong interaction in rocky subtidal systems of eastern Canada, 1970-1980. Neth. J. Sea Res. 116: $4414-4233$

Marsh, A. G., Harvey, H. R., Gremare, A., Tenore, K. R. (1990). Dietary effects on oocyte yolk composition in Capitella sp.I (Annelida: Polychaeta) fatty acids and sterols. Mar. Biol. 106: 369-374

Mayzaud, P., Eaton, C. A., Ackman, R. G. (1976). The occurrence and distribution of octadecapentaenoic acid in a natural plankton population. A possible food chain index. Lipids $11.858-862$
Moshchenko, A. V., Gladkov, A. V (1991). Distribution of Cerianthus sp. community and feeding of macrozoobenthos in Kraternaya Bight. [n: Shallow-water vents and ecosystem of Kraternaya Bight (Volcano Ushishir, Kurile Islands), Vol. 1, Functional characteristics, Part II. DVO RAN, Vladivostok, p. 96-113 (in Russian)

Namsaraev, B. B. (1992). Microbial decomposition of organic matter in anaerobic zone of aquatic system. Ph.D. thesis Inst. Microbiology, Moscow (in Russian)

Nichols, P. D, Johns, R. B., Klumpp, D. W. (1982). Study of food chains in seagrass communities. 1. Lipid components of the seagrasses Posidonia australis and Heterozostera tasmanica as indicators of carbon source. Phytochemistry 21 : $1613-1621$

Nichols, P. D, Klumpp, D. W, Johns, R. B. (1986). Liid components and utilization in consumers of a seagrass community: an indication of carbon source. Comp. Biochem. Physiol. B 83: 103-113

Peterson, B. J, Garritt, R. H., Howarth, R. W. (1985). Multiple stable isotopes used to trace the flow of organic matter in estuarine food webs. Science 227: 1361-1363

Sargent, J. R., Parkes, R. J., Mueller-Harvey, I., Henderson, R. J. (1987). Lipid biomarkers in marine ecology. In: Sleigh M. A. (ed.) Microbes in the sea. Ellis Horwood Ltd, Chichester, p. $119-138$

Sargent, J. R., Whittle, K. J. (1981). Lipids and hydrocarbons in the marine food web. In: Longhurst, A. R. (ed.) Analysis of marine ecosystems. Academic Press, London, $p$ $491-533$

Sorokin, Y. I., Sorokin, P. Y., Zakuskina, O. Y (1993). Functional characteristics of the microplankton in the zones of the shallow-water volcanic activity - the Craternaya Bay, Kurile Isle, a study case. Zh. Obshch. Biol. 54: 223-242

Starynin, D. A., Gorlenko, V. M., Ivanov, M. V., Karnachuk, O. V., Namsaraev, B. B. (1989). Algobacterial mats of Kraternaya Bay (Kurile Islands). Biol. Morya 3: 70-77

Stein, J. L. (1984). Subtidal gastropods consume sulfur-oxidizing bacteria - evidence from coastal hydrothermal vents. Science 223: 696-698

Svetashev, V. I., Levin, V. S., Cham Ngok Lam, Do Tuet Nga (1991). Lipids and fatty acid composition of holothurians from tropical and temperate waters. Comp. Biochem. Physiol. B 98: 489-494

Takagi, T., Kaneniwa, M., Itabachi, Y., Ackman, R. G. (1986). Fatty acids in Echinoidea: unusual cis-5-olefinic acids as distinctive lipid components in the sea urchins. Lipids 21: $558-565$

Tarasov, V. G., Propp، M. V., Propp, L. N., Zhirmunsky, A. V., Namsaraev, B. B., Gorlenko, V. M., Starynin, D. A. (1990). Shallow-water gasohydrothermal vents of Ushishir Volcano and the ecosystem of Kraternaya Bight (Kurile Islands). P.S.Z.N. I: Mar. Ecol. 11, 1-23

Tarasov, V. G., Zhirmunsky, A. V. (1989). Ecosystem studies in Kraternaya Bight, Kurile Islands. Biol. Morya 3: 4-12

Trager, G. C., DeNiro, M. J. (1990). Chemoautotrophic sulfur bacteria as a food source for mollusks at intertidal hydrothermal vents - evidence from stable isotopes. Veliger 33: 359-362

Volkman, J. K., Bavor, H. J., Gillan, F. T., Johns, R. B., Perry, G. J. (1980). Microbial lipids of an intertidal sediment. 1. Fatty acids and hydrocarbons. Geochim. Cosmochim. Acta 44: $1133-1143$

Volkman, J. K., Jeffrey, S. W., Nichols, P. D., Rogers, G. I., Garland, C. D. (1989). Fatty acid and lipid composition of 10 species of microalgae used in mariculture. J. exp. mar Biol. Ecol. 128: 219-240

Wenne, R, Polak, L. (1989). Lipid-composition and storage in 
the tissues of the bivalve, Macoma balthica. Biochem. Syst. Ecol. 17: 583-587

Wilkinson, S. G. (1988). Gram negative bacteria. In: Ratledge, C., Wilkinson, S. G. (eds.) Microbial lipids, Vol. 1. Academic Press, London, p. 299-488

Zhukova, N. V., Kharlamenko, V. I., Svetashev, V I., Rodionov, I. A. (1992). Fatty acids as markers of bacterial symbionts of marine bivalve molluscs. J. exp. mar. Biol. Ecol.

This article was submitted to the editor
162: $253-263$

Zhukova, N. V., Kharlamenko, V. [., Gebruk, A. V. (1991) Fatty acids of Axinopsida orbicula - potential for detection of symbiosis with chemoautotrophic bacteria. In: Shallow-water vents and ecosystem of Kraternaya Bight (Volcano Ushishir, Kurile Islands), Vol. 1. Functional characteristics, Part II. DVO RAN, Vladivostok, p. 63-78 (in Russian)

Manuscript first received: October 20,1993

Revised version accepted: September 12, 1994 